\title{
Quantum-chemical studies of homoleptic iridium(III) complexes in OLEDs: fac versus mer isomers
}

\author{
Izabela Grzelak ${ }^{1}$ (D) $\cdot$ Bartosz Orwat $^{1,2} \cdot$ Ireneusz Kownacki $^{1,2} \cdot$ Marcin Hoffmann ${ }^{1}$
}

Received: 30 November 2018 / Accepted: 15 April 2019 / Published online: 10 May 2019

(C) The Author(s) 2019

\begin{abstract}
A series of facial $\mathbf{f a c}$-[Ir(5-R-bzq $\left.)_{3}\right]$ and meridional mer-[Ir(5-R-bzq $\left.)_{3}\right] \operatorname{Ir}(\mathrm{III})$ complexes bearing benzo[ $\left.h\right]$ quinoline-based ligands have been studied with the help of density functional theory (DFT) methods. A detailed electronic structure comparison of the two isomers has been addressed to point out the differences in their stability and photophysical properties. An influence of substituent impact on optical and electronic properties of $\operatorname{Ir}(\mathrm{III})$ homoleptic complexes was also explored by introducing into the cyclometalated ligands substituents characterized with different electronic properties, e.g., $\mathrm{R}=\mathrm{H}, \mathrm{F}, \mathrm{OPh}, \mathrm{NMe}_{2}, \mathrm{C}_{6} \mathrm{~F}_{5}$, and $p$ $\mathrm{C}_{6} \mathrm{H}_{4}-\mathrm{NPh}_{2}$. The results herein show that fac and mer isomers exhibit remarkable differences in stability and photophysical properties. The introduction of different functional groups into bzq ligands, despite very similar geometrical structures, significantly affected HOMO and LUMO energy levels and energy gaps of the examined Ir(III) complexes.
\end{abstract}

Keywords Ir(III) complexes · DFT · Fac-mer isomer factors $\cdot$ Substitution effects $\cdot$ Organic light-emitting diodes

\section{Introduction}

Phosphorescent transition-metal complexes have recently caught significant attention because of their unique photophysical properties, which are useful in applications, such as dopants for OLEDs (organic light-emitting diode) [1-5], light-emitting electrochemical cells (LECs) [6-9], dye-sensitized solar cells [3, 10], water splitting [11, 12], and biological phosphorescent labels and sensors [13, 14]. Those complexes exhibit phosphorescence due to very strong spin-orbit coupling, which causes mutual isoenergetic transition from the singlet to the triplet state and conversely, known

This paper belongs to Topical Collection 8 th conference on Modeling \& Design of Molecular Materials (MDMM 2018)

Electronic supplementary material The online version of this article (https://doi.org/10.1007/s00894-019-4035-2) contains supplementary material, which is available to authorized users.

Izabela Grzelak

izabela.grzelak@amu.edu.pl

1 Faculty of Chemistry, Adam Mickiewicz University in Poznan, St. Umultowska 89b, 61-614 Poznan, Poland

2 Center for Advanced Technologies, Adam Mickiewicz University in Poznan, St. Umultowska 89c, 61-614 Poznan, Poland as intersystem crossing (ISC) [15]. Many families of heavy metal complexes, such as Os(II) [16], Ru(II) [17], Pt (II) [17], and $\operatorname{Ir}(\mathrm{III})$ [18-20], have been extensively investigated with the aim of better understanding their photophysical properties. In particular, cyclometalated iridium(III) complexes are very promising for a large range of luminescence-based applications because of their high photoluminescence quantum yields, relatively short excited-state lifetime, and general thermal and electrochemical stability [21-59]. Another interesting feature is the possibility of tuning the emission energy of Ir(III) complexes from blue to red light over the entire visible range, which is a key step for realizing the full-color displays and large-area solid-state lighting in OLED fields [4, 5, 19]. Emission color tuning is possible by varying emitter's HOMO-LUMO gap [60], either by using various ligand cores or playing with acceptor/donor character of the substituents on the main or the ancillary ligands.

In recent years, a number of intensive studies have been carried out to design and synthesize phosphorescent materials for highly efficient OLEDs. Nevertheless, most of the studies concerning this subject have been focused on the synthesis and photophysical properties of neutral and ionic iridium(III) compounds, those stabilized with various types of cyclometalated ligands built on the basis of 2phenylpyridine (ppy) cores [61]. However, there has been little attention paid to iridium(III) compounds containing 
cyclometalating ligands, such as benzo[h]quinoline (bzq), which is an analogue of ppy [62]. This fact has prompted us to focus on homoleptic iridium(III) compounds with bzq ligands. They are termed homoleptic when three identical chelating ligands are present in the complex structure as illustrated below.

Furthermore, there are two possible isomers, facial and meridional ( $f a c$ and $m e r$ ), for such complexes having three identical but unsymmetrical bidentate ligands [63-66] (Fig. 1).

In this work, we present a series of iridium(III) complexes with three cyclometalating ligands based on bzq. We report herein an extensive theoretical investigation of the structural, electrochemical, and photophysical properties of these compounds. A systematic comparison of $f a c$ and mer isomer pairs aimed at identification of the differences in their stability and photophysical properties is presented. In addition, as HOMO and LUMO energy levels are likely to be affected by the substitution effects, we were interested in red or blue shifts in the emissions of these fac and mer Ir(III) complexes.

\section{Computational details and theory}

The ground-state geometries were fully optimized using the density functional theory (DFT) [67] with B3LYP [68-70], M06 [71], and WB97XD [72] functionals. These methods were selected on the basis of the results from extensive comparative studies, they are also recommended for robust and fast calculations for large organometallic compounds [68-72]. The 6-31G $(\mathrm{d}, \mathrm{p})$ basis set was used for $\mathrm{H}, \mathrm{C}, \mathrm{N}, \mathrm{O}$, and $\mathrm{F}$ atoms [73] and LANL2DZ basis set was adopted for the Ir atom [74]. A relativistic effective core potential (ECP) on Ir replaced the inner core electrons leaving the outer core $\left(5 s^{2} 5 p^{6}\right)$ electrons and the valence electrons $\left(5 d^{6}\right)$ of $\operatorname{Ir}(\mathrm{III})$.
There were no symmetry constraints on these $\operatorname{Ir}(\mathrm{III})$ complexes during the geometry optimizations. Vibrational analyses for the optimized structures of isolated molecules were performed to verify if a given structure corresponded to potential energy minima and to calculate zero-point vibrational energies, entropies, and thermal corrections for Gibbs free energies. Solvent-solute interactions were taken into account with the aid of the polarizable continuum model (PCM) [75-77] and acetonitrile or dichloromethane as the solvent usually used in experimental studies [78, 79]. All calculations were carried out with Gaussian09 software package [80] in PL-Grid infrastructure.

In this paper, we focused our attention on several $\mathrm{R}$ substituted $\left(\mathrm{R}=\mathrm{H}, \mathrm{F}, \mathrm{OMe}, \mathrm{OPh}, \mathrm{NMe}_{2}, \mathrm{C}_{6} \mathrm{~F}_{5}\right.$, and $\mathrm{p}$ $\left.\mathrm{C}_{6} \mathrm{H}_{4}-\mathrm{NPh}_{2}\right) \operatorname{Ir}(5-\mathrm{R}-\mathrm{bzq})_{3}$ complexes in both fac and mer isomeric forms. These tris-cyclometalated $\operatorname{Ir}(\mathrm{III})$ complexes were studied to explore preferences toward fac or mer isomers of $\operatorname{Ir}(\mathrm{III})$ complexes.

\section{Results and discussion}

\section{Geometries in the ground state $\left(\mathrm{S}_{0}\right)$}

The representative optimized structures of $f a c-\left[\operatorname{Ir}(\mathrm{bzq})_{3}\right]$ and $m e r-\left[\operatorname{Ir}(\mathrm{bzq})_{3}\right]$ in the ground state $\left(\mathrm{S}_{0}\right)$ along with the numbering of some key atoms are shown in Fig. 2. In order to investigate the solvent effect, the ground-state geometry optimization was also carried out within the PCM method [75-77]. The selected optimized geometry parameters for $\left[\operatorname{Ir}(\mathrm{bzq})_{3}\right]$ in the gas phase and the acetonitrile environment are summarized in Table 1S (Supplementary materials).

Table 1S (Supplementary materials) illustrates the parameters of Ir-ligand bond lengths and bond angles in the gas phase and $\mathrm{CH}_{3} \mathrm{CN}$ media for $\left[\operatorname{Ir}(\mathrm{bzq})_{3}\right]$. Calculated $\mathrm{Ir}-\mathrm{N}, \mathrm{Ir}-\mathrm{C}$, and

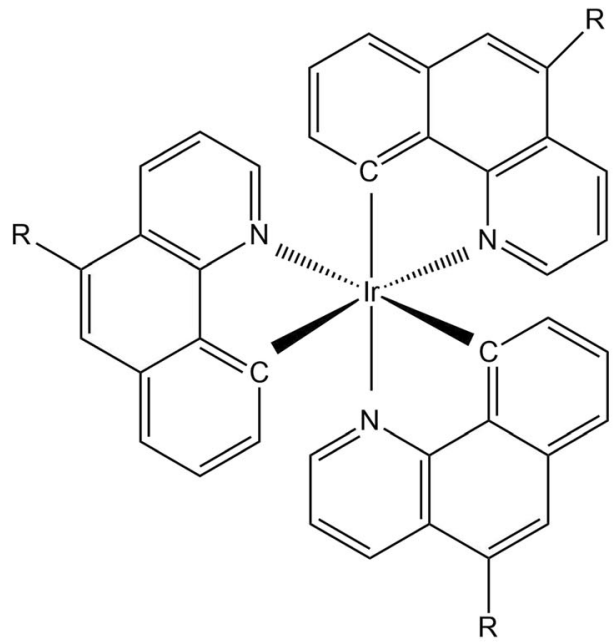

fac isomer

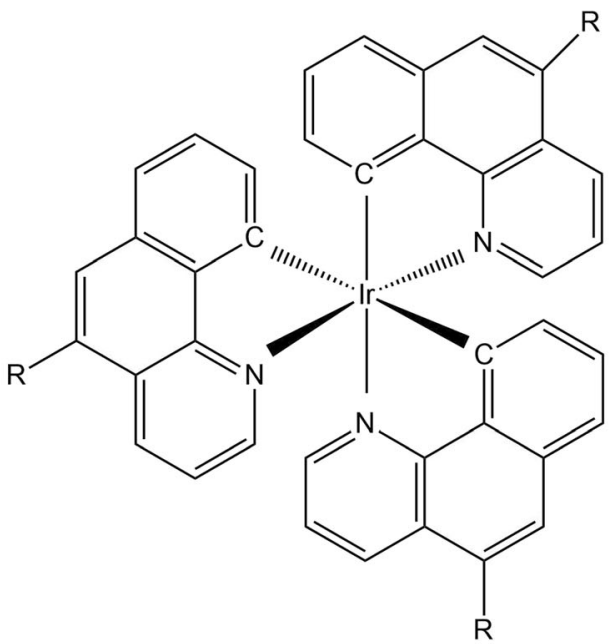

mer isomer
1: $\mathrm{R}=\mathrm{H}$

2: $\mathrm{R}=\mathrm{F}$

3: $\mathrm{R}=\mathrm{OMe}$

4: $\mathrm{R}=\mathrm{OPh}$

5: $\mathrm{R}=\mathrm{NMe}_{2}$

6: $\mathrm{R}=\mathrm{C}_{6} \mathrm{~F}_{5}$

7: $\mathrm{R}=\mathrm{p}-\mathrm{C}_{6} \mathrm{H}_{4}-\mathrm{NPh}_{2}$

Fig. 1 Chemical formulas of Ir(III) complexes examined 


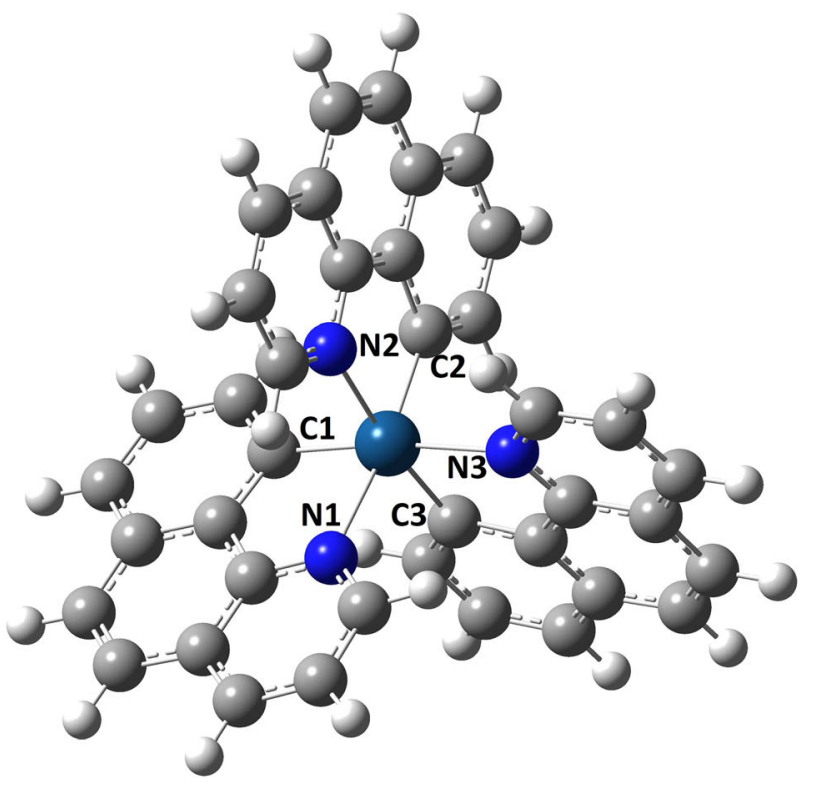

$f a c-\left[\operatorname{Ir}(\mathbf{b z q})_{3}\right]$

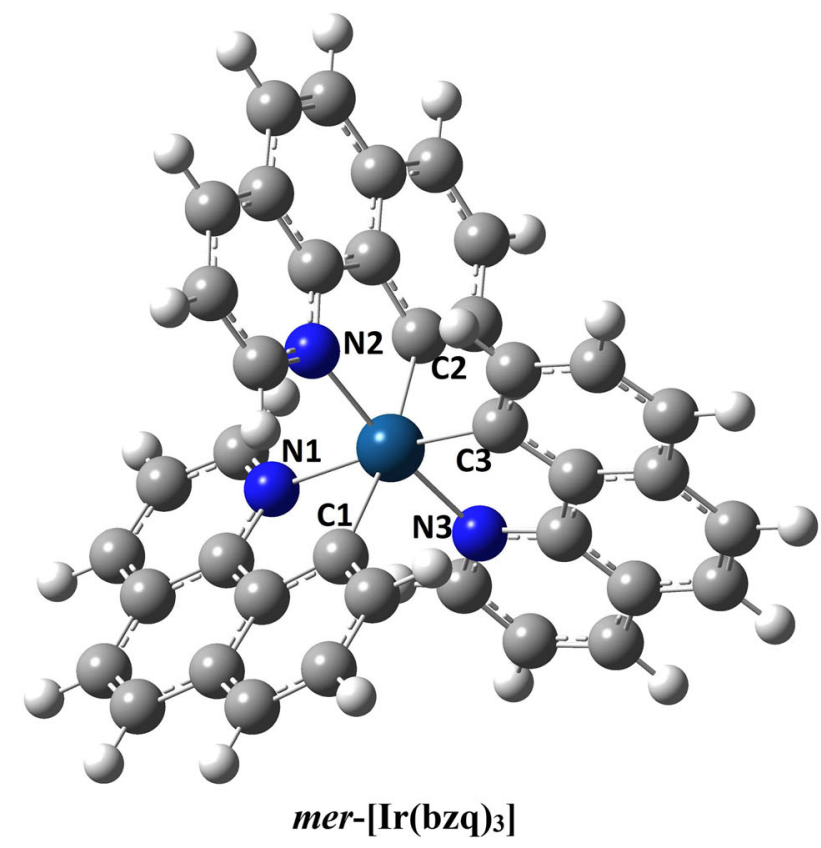

Fig. 2 Optimized geometries of $f a c-\left[\operatorname{Ir}(\mathrm{bzq})_{3}\right]$ and $m e r-\left[\operatorname{Ir}(\mathrm{bzq})_{3}\right]$ in the ground state

Ir-O bond lengths are slightly larger in the gas phase than in the acetonitrile environment. The maximum deviation in bond distances between coordinating atoms and $\operatorname{Ir}($ III) is $0.008 \AA$, while changes in bond angles are less than $1.0^{\circ}$. However, the geometries of all complexes present similar features, indicating that the solvent environment has little effect on the geometry of the complexes.

The optimized structures showed the expected pseudooctahedral coordination geometry around the iridium center (the corresponding parameters provided as Supplementary material). According to Fig. 2 and Table 1S, two coordinated atoms $(\mathrm{N}(2)$ and $\mathrm{C}(3))$ in the fac isomer are in trans position and the valence angle of $\mathrm{N}(2)-\mathrm{Ir}-\mathrm{C}(3)$ is nearly $180^{\circ}$, while the coordinating atoms $(\mathrm{N}(3)$ and $\mathrm{C}(2))$ are in cis position and the valence angle value $\mathrm{N}(3)-\mathrm{Ir}-\mathrm{C}(2)$ is close to $90^{\circ}$. Furthermore, two valence angles between the coordinating atoms from the same ligand and the central iridium atom $\mathrm{N}(2)-\mathrm{Ir}-\mathrm{C}(1)$ and $\mathrm{N}(1)-\mathrm{Ir}-\mathrm{C}(3)$ are nearly identical, ca. $90^{\circ}$ (Table $1 \mathrm{~S}$ and Fig. 1). Likewise, the valence angles $\mathrm{N}(2)-\mathrm{Ir}-$
$\mathrm{N}(1)$ and $\mathrm{C}(1)-\mathrm{Ir}-\mathrm{C}(3)$ in the mer isomer are also ca. $90^{\circ}$. For fac- $\left[\operatorname{Ir}(\mathrm{bzq})_{3}\right], \mathrm{Ir}-\mathrm{N}$ bonds lengths $(\mathrm{Ir}-\mathrm{N} 1, \mathrm{Ir}-\mathrm{N} 2, \mathrm{Ir}-\mathrm{N} 3)$ are in the range of $2.195-2.199 \AA$, while $\mathrm{Ir}-\mathrm{C}$ bonds $(\mathrm{Ir}-\mathrm{C} 1, \mathrm{Ir}-\mathrm{C} 2$, Ir-C3) vary from 2.033 to $2.035 \AA$ (Table 1). It was found that Ir-C bond lengths are significantly shorter by $\sim 0.15 \AA$ compared to $\mathrm{Ir}-\mathrm{N}$ bonds. A similar electronic environment of $\mathrm{Ir}-$ $\mathrm{C} / \mathrm{Ir}-\mathrm{N}$ bonds leads to their similar bond distance $(0.002 \AA$ and $0.004 \AA$ ). It is also notable that the change of substituent $\left(\mathrm{R}=\mathrm{H}, \mathrm{F}, \mathrm{OMe}, \mathrm{OPh}, \mathrm{NMe}_{2}, \mathrm{C}_{6} \mathrm{~F}_{5}\right.$, and $\left.\mathrm{p}-\mathrm{C}_{6} \mathrm{H}_{4}-\mathrm{NPh}_{2}\right)$ in position 5 in bzq ligand very slightly affects $\mathrm{Ir}-\mathrm{C}$ and $\mathrm{Ir}-\mathrm{N}$ bond lengths of $f a c$ complexes containing these functionalized ligands.

In the case of complex $m e r-\left[\operatorname{Ir}(\mathrm{bzq})_{3}\right], \mathrm{Ir}-\mathrm{C}$ and $\mathrm{Ir}-\mathrm{N}$ bond lengths are different from those in the fac isomer. In $\mathrm{mer}$ configuration, two donor carbon atoms (C1 vs. C2) and two donor nitrogen atoms ( 2 vs. N3) adopt a trans orientation, leaving the remaining $\mathrm{C} 3$ and $\mathrm{N} 1$ atoms trans to each other. The different local environments result in different bond lengths for these Ir-C and Ir-N bonds. For instance, owing

Table 1 Selected calculated bond distances $(\AA)$ in the ground states $\left(\mathrm{S}_{0}\right)$ for the studied complexes

\begin{tabular}{|c|c|c|c|c|c|c|c|c|c|c|c|c|c|c|}
\hline & \multicolumn{2}{|l|}{1} & \multicolumn{2}{|l|}{2} & \multicolumn{2}{|l|}{3} & \multicolumn{2}{|l|}{4} & \multicolumn{2}{|l|}{5} & \multicolumn{2}{|l|}{6} & \multicolumn{2}{|l|}{7} \\
\hline & $f a c$ & mer & $f a c$ & mer & $f a c$ & mer & $f a c$ & mer & $f a c$ & mer & $f a c$ & mer & $f a c$ & mer \\
\hline $\mathrm{Ir}-\mathrm{C} 1$ & 2.035 & 2.117 & 2.035 & 2.117 & 2.033 & 2. 117 & 2.034 & 2.116 & 2.034 & 2.115 & 2.034 & 2.114 & 2.033 & 2.113 \\
\hline $\mathrm{Ir}-\mathrm{C} 2$ & 2.035 & 2.106 & 2.035 & 2.106 & 2.034 & 2.105 & 2.034 & 2.104 & 2.033 & 2.102 & 2.033 & 2.101 & 2.033 & 2.102 \\
\hline $\mathrm{Ir}-\mathrm{C} 3$ & 2.035 & 2.024 & 2.035 & 2.025 & 2.034 & 2.024 & 2.035 & 2.024 & 2.035 & 2.023 & 2.033 & 2.022 & 2.033 & 2.022 \\
\hline $\mathrm{Ir}-\mathrm{N} 1$ & 2.197 & 2.215 & 2.196 & 2.215 & 2.196 & 2.215 & 2.196 & 2.215 & 2.197 & 2.216 & 2.196 & 2.215 & 2.196 & 2.214 \\
\hline $\mathrm{Ir}-\mathrm{N} 2$ & 2.197 & 2.078 & 2.198 & 2.078 & 2.198 & 2.078 & 2.198 & 2.078 & 2.197 & 2.078 & 2.195 & 2.078 & 2.195 & 2.078 \\
\hline $\mathrm{Ir}-\mathrm{N} 3$ & 2.197 & 2.089 & 2.198 & 2.089 & 2.199 & 2.090 & 2.199 & 2.091 & 2.197 & 2.092 & 2.198 & 2.092 & 2.196 & 2.083 \\
\hline
\end{tabular}


to the strong trans influence of carbon atom $\mathrm{C} 3$, Ir- $\mathrm{N}$ bond (Ir-N1) trans to it is much longer (about $0.13 \AA$ ) than the other two Ir-N ones (Ir-N2, Ir-N3, see Table 1 and Fig. 2). It was also found that $\mathrm{Ir}-\mathrm{C}$ and $\mathrm{Ir}-\mathrm{N}$ bond distances follow the trend: $\mathrm{Ir}-\mathrm{C} 1>\mathrm{Ir}-\mathrm{C} 2>\mathrm{Ir}-\mathrm{C} 3$ and $\mathrm{Ir}-\mathrm{N} 1>\mathrm{Ir}-\mathrm{N} 3>\mathrm{Ir}-\mathrm{N} 2$. Moreover, hardly any variation in $\mathrm{Ir}-\mathrm{C}$ and $\mathrm{Ir}-\mathrm{N}$ bond lengths (the differences are $0.005 \AA$ and $0.004 \AA$ ) was observed upon the substituent change in position 5 of these mer complexes.

On the basis of the obtained Gibbs free energies for iridium(III) complexes, populations of conformers were calculated using a standard Boltzmann formalism. The percentage of a conformer $\mathrm{X}$ is given as:

$\% X=\frac{\exp \left(-\frac{\Delta G_{x}^{0}}{R T}\right)}{\sum_{i} \exp \left(-\frac{\Delta G_{i}^{0}}{R T}\right)} \times 100 \%$

where $\Delta \mathrm{G}_{\mathrm{x}}{ }^{0}$ is the relative energy of a conformer X.

The relative free energies of the optimized conformations in the ground state along with their distributions are summarized in Table 2. In all cases, the most energetically preferred structure was the $f a c$ configuration. The relative energy of $f a c-\left[\operatorname{Ir}(5-\mathrm{R}-\mathrm{bzq})_{3}\right]$ in comparison to the $m e r-\left[\operatorname{Ir}(5-\mathrm{R}-\mathrm{bzq})_{3}\right]$ was more favorable from about $8 \mathrm{kcal} \mathrm{mol}^{-1}$ to $9.2 \mathrm{kcal}$ $\mathrm{mol}^{-1}$. As we can see, the fac isomer is more stable than mer, which is consistent with the experimental observations for similar ppy-based complexes [81]. The calculated populations of conformers suggest that virtually only the facial isomers are likely to be observed in the equilibrium.

\section{NMR chemical shifts}

The ${ }^{1} \mathrm{H}$ NMR calculations were carried out for the two isomers of complex $\left[\operatorname{Ir}(\mathrm{bzq})_{3}\right]$ in $\mathrm{CH}_{2} \mathrm{Cl}_{2}$ solvent using PCM model and compared to experimental ${ }^{1} \mathrm{H}$ chemical shifts reported in literature [81]. It must be underlined here that experimental data relate to a mixture of isomers [82] because the isolation of pure facial or meridional isomer was not achieved; as reported by Lamansky et al. [81]: "The $\operatorname{Ir}(\text { bzq })_{3}$ product from this reaction is a mixture of $f a c$ - and mer-isomers. Several wash cycles (acetone and dichloromethane) cause significant enrichment of the mixture in fac-product but still does not allow isolation of a pure facial complex.". Therefore, the experimental data was compared with computational data obtained for both isomers (Table 3). The spectral data of the complexes $f a c-\left[\operatorname{Ir}(\mathrm{bzq})_{3}\right]$ and $m e r-\left[\operatorname{Ir}(\mathrm{bzq})_{3}\right]$ have been summarized in Table $2 \mathrm{~S}$ and Table $3 \mathrm{~S}$ (Supplementary materials).

Table 2 Comparison of fac/mer relative energies in the ground state obtained in B3LYP calculations and population of obtained conformers

\begin{tabular}{|c|c|c|c|c|c|c|c|}
\hline Species & Conformer & $\begin{array}{l}\text { Relative energy in } \\
\left.\text { vacuum }\left[\mathrm{kcal} \mathrm{mol}^{-1}\right]\right] \\
\text { B3LYP/GEN }\end{array}$ & $\begin{array}{l}\text { Entropy } \\
{\left[\text { cal mol }^{-1} * \mathrm{~K}\right]} \\
\text { B3LYP/GEN }\end{array}$ & $\begin{array}{l}\text { Thermal correction } \\
\text { to G [hartree] } \\
\text { B3LYP/GEN }\end{array}$ & $\begin{array}{l}\text { Solvation correction } \\
\text { to } \mathrm{G} \text { [hartree] } \\
\text { B3LYP/GEN }\end{array}$ & $\begin{array}{l}\text { Relative } \Delta \mathrm{G} \\
{\left[\mathrm{kcal} \mathrm{mol}^{-1}\right]} \\
\text { B3LYP/GEN }\end{array}$ & $\begin{array}{l}\text { Population of } \\
\text { conformers } \\
\text { X [\%] }\end{array}$ \\
\hline \multirow[t]{2}{*}{1} & $f a c$ & $0^{\mathrm{a}}$ & 193.690 & 0.458803 & -0.015587 & 0 & $>99.9$ \\
\hline & mer & 8.8 & 192.757 & 0.459205 & -0.014579 & 9.1 & $<0.1$ \\
\hline \multirow[t]{2}{*}{2} & $f a c$ & $0^{\mathrm{b}}$ & 206.874 & 0.430771 & -0.014756 & 0 & $>99.9$ \\
\hline & mer & 8.9 & 205.930 & 0.431161 & -0.013616 & 9.2 & $<0.1$ \\
\hline \multirow[t]{2}{*}{3} & $f a c$ & $0^{\mathrm{c}}$ & 231.231 & 0.546774 & -0.017932 & 0 & $>99.9$ \\
\hline & mer & 9.2 & 230.219 & 0.547219 & -0.018567 & 9.4 & $<0.1$ \\
\hline \multirow[t]{2}{*}{4} & $f a c$ & $0^{\mathrm{d}}$ & 294.705 & 0.681898 & -0.016932 & 0 & $>99.9$ \\
\hline & mer & 7.9 & 293.201 & 0.680728 & -0.017243 & 8.4 & $<0.1$ \\
\hline \multirow[t]{2}{*}{5} & $f a c$ & $0^{\mathrm{e}}$ & 251.058 & 0.662387 & -0.018438 & 0 & $>99.9$ \\
\hline & mer & 8.9 & 249.993 & 0.662842 & -0.017271 & 9.2 & $<0,1$ \\
\hline \multirow[t]{2}{*}{6} & $f a c$ & $0^{\mathrm{f}}$ & 248.126 & 0.66722 & -0.195789 & 0 & $>99.9$ \\
\hline & mer & 7.9 & 336.044 & 0.638312 & -0.186478 & 8.6 & $<0.1$ \\
\hline \multirow[t]{2}{*}{7} & $f a c$ & $0^{\mathrm{g}}$ & 436.178 & 1.161229 & -0.029694 & 0 & $>99.9$ \\
\hline & mer & 8.0 & 435.391 & 1.160379 & -0.028532 & 9.1 & $<0.1$ \\
\hline
\end{tabular}

Absolute energy baselines [in hartree]:

a 1769.811996

b 2067.526347

c 2111.509138

d 2689.066343

e 2171.723886

f 3948.794651

g 4011.872968 
Table 3 Calculated $1 \mathrm{H}$ NMR chemical shifts (ppm) together with the experimental data for $f a c-\left[\operatorname{Ir}(\mathrm{bzq})_{3}\right]$ and mer-[Ir(bzq $\left.)_{3}\right]$

\begin{tabular}{ll}
\hline Experimental $^{\mathrm{a}}$ & Calculated \\
\hline 8.31 & $8.31(\mathrm{H} 14$, mer $)$ \\
8.19 & $8.22(\mathrm{H} 7$, mer $)$ \\
8.12 & $8.12(\mathrm{H} 2$, mer $)$ \\
8.03 & $8.03(\mathrm{H} 4$, fac $)$ \\
7.90 & $7.85(\mathrm{H} 17$, mer $)$ \\
7.60 & $7.67(\mathrm{H} 10$, mer $)$ \\
7.47 & $7.67(\mathrm{H} 13$, mer $)$ \\
7.39 & $7.53(\mathrm{H} 2$, fac $)$ \\
7.22 & $7.50(\mathrm{H} 20$, mer $)$ \\
7.14 & $7.49(\mathrm{H} 6$, mer $)$ \\
7.07 & $7.46(\mathrm{H} 24$, mer $)$ \\
6.96 & $7.46(\mathrm{H} 15$, mer $)$ \\
6.8 & $7.39(\mathrm{H} 8$, fac $)$ \\
6.57 & $7.18(\mathrm{H} 8$, mer $)$ \\
\hline
\end{tabular}

${ }^{\text {a Ref. [81] }}$

As shown in Fig. 1S (Supplementary materials), calculated chemical shifts of ${ }^{1} \mathrm{H}$ NMR spectra for $f a c$ - $\left[\operatorname{Ir}(\mathrm{bzq})_{3}\right]$ and $m e r-\left[\operatorname{Ir}(\mathrm{bzq})_{3}\right]$ are in good agreement with the experimental data, the obtained correlation equaled 0.95 . The comparison of calculated and experimental data let us assume that signals in experimental spectrum come from both isomers. In the ${ }^{1} \mathrm{H}$ NMR spectrum of $f a c$ - $\left[\operatorname{Ir}(\mathrm{bzq})_{3}\right]$, eight protons of a single bzq ligand are displayed because the three ligands surrounding the iridium atom are magnetically equivalent. The signals appearing at $8.03 \mathrm{ppm}, 7.53 \mathrm{ppm}$, and $7.39 \mathrm{ppm}$ originate from $f a c-\left[\operatorname{Ir}(\mathrm{bzq})_{3}\right]$ and the other signals originate from $m e r-\left[\operatorname{Ir}(\mathrm{bzq})_{3}\right]$.

\section{Frontier molecular orbitals analysis}

Results from numerous literature reports indicated that frontier molecular orbitals analysis constitutes a useful proxy for experimentally recorded photophysical properties of iridium(III) complexes [78, 79, 82-84]. It is known that frontier molecular orbitals (FMO) of complex ground state $\mathrm{S}_{0}$ are related to its spectral properties [86]. Emission color of iridium(III) complexes can be adjusted by changing their HOMO-LUMO bandgap, which can be achieved on the course of ligand functionalization with electron-donating and electronwithdrawing substituents [86], and values of HOMO-LUMO gaps predicted for Ir(III) complexes by DFT methods showed surprisingly good correlation with the experimentally recorded values of energies of emitted photons even in the case of phosphorescence, see for example [21, 22, 83-85, 87-90]. Contour plots of frontier orbitals of both $\left[\operatorname{Ir}(\mathrm{bzq})_{3}\right]$ isomers are depicted in Fig. 3, while the visualizations of complexes 2-7 are collected in Table 4S (Supplementary materials).

As shown in Fig. 3, HOMO of $f a c-\left[\operatorname{Ir}(\mathrm{bzq})_{3}\right]$ is predominantly localized on the iridium atom and over benzo moieties of the three bzq ligands. Similarly, LUMO is localized mostly on pyrido fragments of the bzq ligands. It is also noteworthy that change of the substituent in position $5(\mathrm{R}=\mathrm{H}, \mathrm{F}, \mathrm{OMe}$, $\mathrm{OPh}, \mathrm{NMe}_{2}, \mathrm{C}_{6} \mathrm{~F}_{5}$, and $\mathrm{p}-\mathrm{C}_{6} \mathrm{H}_{4}-\mathrm{NPh}_{2}$ ) causes minor effects
Fig. 3 Contour plots of HOMOs (bottom) and LUMOs (top) of $f a c-\left[\operatorname{Ir}(\mathrm{bzq})_{3}\right]$ (left) and mer$\left[\operatorname{Ir}(\mathrm{bzq})_{3}\right]$ (right)

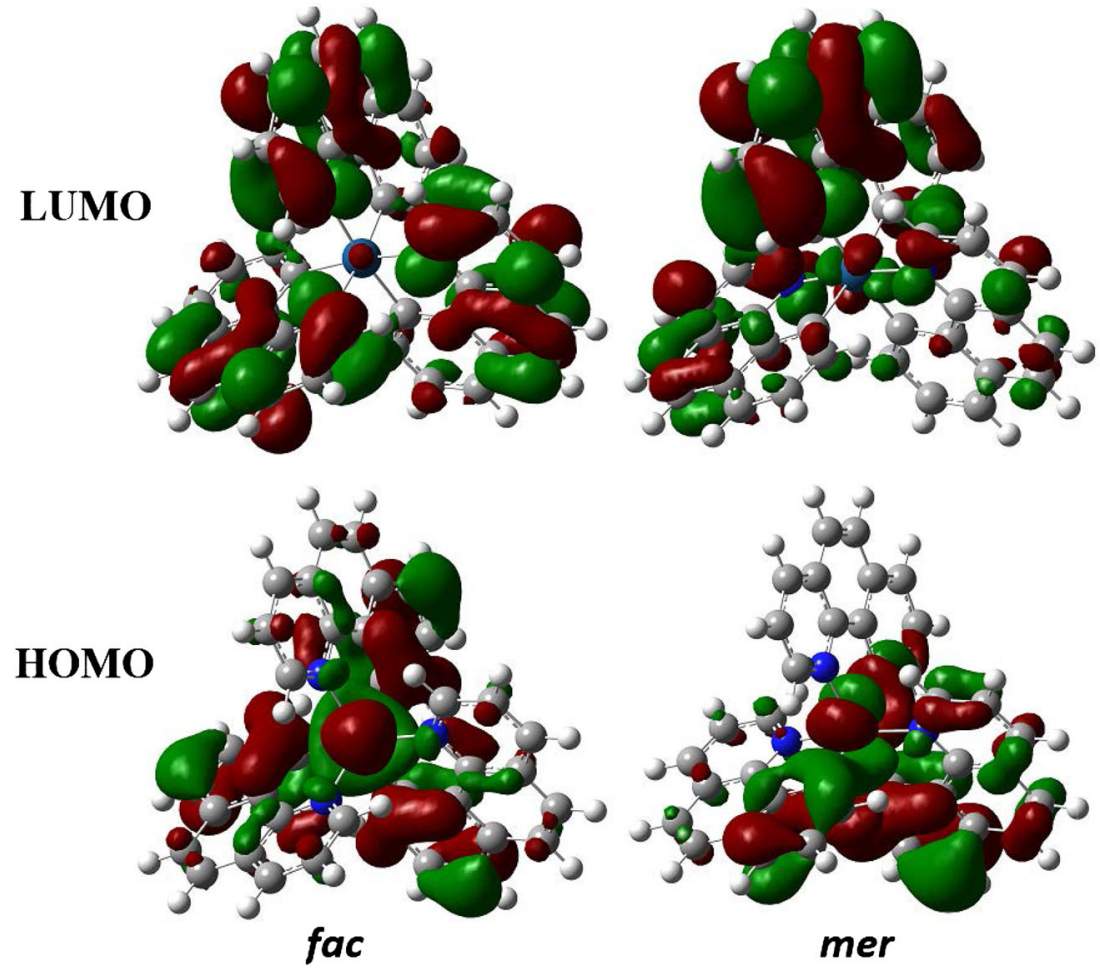


Fig. 4 Energy levels and HOMO-LUMO energy gaps of the studied complexes (in eV) calculated at the B3LYP/ LANL2DZ/6-311++G(d,p) level of theory

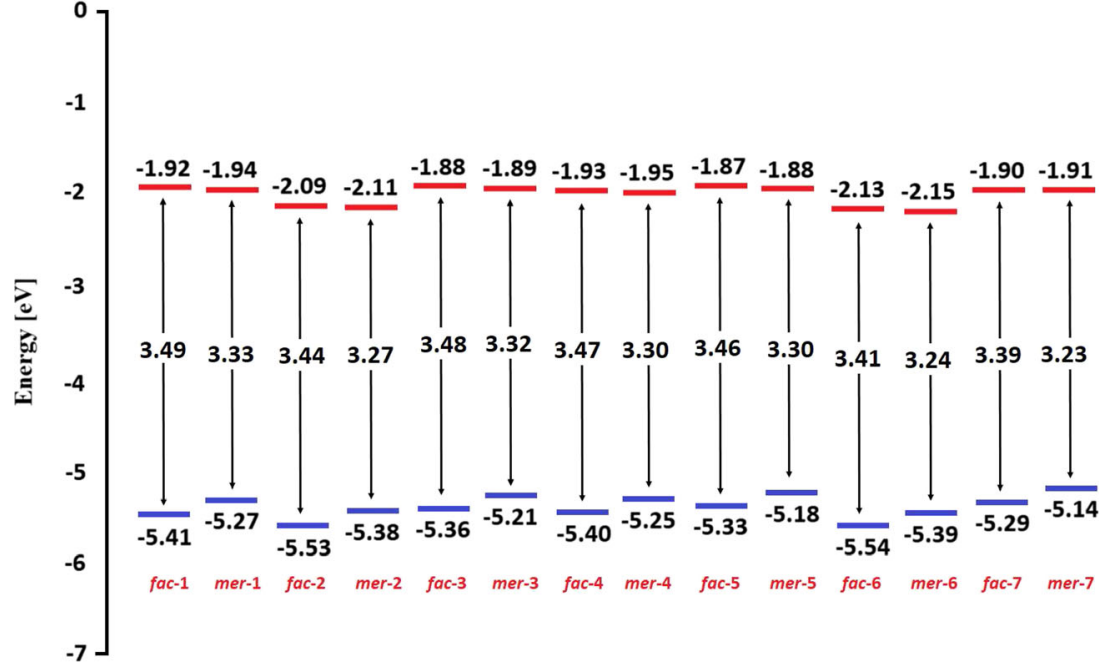

on the electron densities of the HOMOs and LUMOs of complexes 1-7 (Supplementary material).

In the case of mer isomers, HOMO dominants residues on Ir metal center and benzo moieties of two bzq ligands containing $\mathrm{C} 1$ and $\mathrm{C} 3$ donor atoms. LUMO of mer-[ $\left.\operatorname{Ir}(\mathrm{bzq})_{3}\right]$ is mainly spread over pyrido moieties of the bzq ligands containing $\mathrm{N} 1$ and N2 donor atoms. Similarly, as in the case of fac-[Ir(bzq) $\left.)_{3}\right]$, HOMO and LUMO distributions seem not to be very sensitive to substituents influence.

Energy levels of frontier orbitals and HOMO-LUMO energy gap for studied complexes are plotted in Fig. 4. It can be seen that the impact of $\mathrm{R}$ substituent variation on HOMO and LUMO energy levels for $f a c$ - $\left[\operatorname{Ir}(5-\mathrm{R}-\mathrm{bzq})_{3}\right]$ series follows the same trend as in the case of $m e r-\left[\operatorname{Ir}(5-\mathrm{R}-\mathrm{bzq})_{3}\right]$ series. In general, electron-withdrawing substituents $\left(\mathrm{R}=\mathrm{F}, \mathrm{C}_{6} \mathrm{~F}_{5}\right)$ are responsible for lowering energy levels of HOMO and LUMO, but does not extend the HOMO-LUMO energy gap in comparison to unmodified [ $\left.\operatorname{Ir}(\mathrm{bzq})_{3}\right]$. According to that, electrondonating groups $\left(\mathrm{R}=\mathrm{OMe}, \mathrm{OPh}, \mathrm{NMe}_{2}\right.$, and $\mathrm{p}-\mathrm{C}_{6} \mathrm{H}_{4}-\mathrm{NPh}_{2}$ ) cause a higher increase of HOMO and LUMO levels in reference to unmodified $\left[\operatorname{Ir}(\mathrm{bzq})_{3}\right]$. In addition, such substituents induce more destabilization of HOMO than LUMO, resulting in smaller HOMO-LUMO energy gaps $\left(\mathrm{E}_{\mathrm{g}}\right)$.

Moreover, it should also be pointed out that LUMO levels of complexes in fac configuration are similar to their mer analogues, while HOMO energy is decreased in comparison to mer isomers, thereby leading to larger energy gaps of $f a c-\left[\operatorname{Ir}(5-\mathrm{R}-\mathrm{bzq})_{3}\right]$ than the corresponding mer-[Ir(5-R-bzq) $\left.)_{3}\right]$ (Fig. 4). The energies of FMOs calculated with the use of different methods were listed in Tables 5S-7S in Supplementary materials.

\section{Conclusions}

Electronic structures and photophysical properties of facial and meridional $\operatorname{Ir}(\mathrm{III})$ complexes $\left(f a c\right.$ - $\left[\operatorname{Ir}(5-\mathrm{R}-\mathrm{bzq})_{3}\right]$ and $m e r-[\operatorname{Ir}(5-\mathrm{R}-$ bzq) $)_{3}$ ]) series were examined with the use of density functional theory. For all of the studied iridium complexes, a greater thermodynamic stability of $f a c$ isomers in reference to mer isomers were observed. DFT calculation with different functionals (B3LYP, M06, and WB97XD) showed approximately $9 \mathrm{kcal}$ $\mathrm{mol}^{-1}$ stabilization of total energy in favor of $f a c$ isomers. The differences in the ligand orientation around the metal center causes the HOMO energies of meridional isomers to be higher than those of facial forms, while LUMO energies are roughly the same. Consequently, HOMO-LUMO energy gaps are wider for $f a c-\left[\operatorname{Ir}(5-\mathrm{R}-\mathrm{bzq})_{3}\right]$ than the corresponding $m e r-\left[\operatorname{Ir}(5-\mathrm{R}-\mathrm{bzq})_{3}\right]$. The obtained results show that geometrical structures of the complexes are hardly affected by change of substituent $(\mathrm{R}=\mathrm{H}, \mathrm{F}$, $\mathrm{OPh}, \mathrm{NMe}_{2}, \mathrm{C}_{6} \mathrm{~F}_{5}$, and $\mathrm{p}-\mathrm{C}_{6} \mathrm{H}_{4}-\mathrm{NPh}_{2}$ ) in position 5 of cyclometalated ligand, while HOMO and LUMO energy levels are significantly influenced by the substitution effects. In particular, the incorporation of electron-donating substituent $\mathrm{p}-\mathrm{C}_{6} \mathrm{H}_{4}-$ $\mathrm{NPh}_{2}$ leads to decreased HOMO-LUMO gap, thus suggesting red shift on the absorption/emissions spectra lines. In addition, the predicted change of HOMO and LUMO energy levels for both fac and mer forms are similar. Moreover, we suggested which signals in ${ }^{1} \mathrm{H}$ NMR spectra are likely to correspond to fac or mer isomers, which should help in interpretation of experimental NMR spectra.

Acknowledgments This work was supported by the National Science Centre (Poland) through grant no. UMO-2013/11/B/ST5/01334. This research was supported in part by PL-Grid Infrastructure.

Author contributions The manuscript was written through contributions of all authors. All authors have given approval to the final version of the manuscript.

\section{Compliance with ethical standards}

Competing interests The authors declare no competing financial interest. 
Abbreviations OLED, Organic light-emitting diode; ISC, Intersystem crossing; PLQY, Photoluminescence quantum yield; FMO, Frontier molecular orbitals; HOMO, Highest occupied molecular orbital; LUMO, Lowest occupied molecular orbital; DFT, Density functional theory; NMR, Nuclear magnetic resonance

Open Access This article is distributed under the terms of the Creative Commons Attribution 4.0 International License (http:// creativecommons.org/licenses/by/4.0/), which permits unrestricted use, distribution, and reproduction in any medium, provided you give appropriate credit to the original author(s) and the source, provide a link to the Creative Commons license, and indicate if changes were made.

\section{References}

1. Flamigni L, Barbieri A, Sabatini C et al (2007) Photochemistry and photophysics of coordination compounds: iridium. Photochemistry and Photophysics of coordination compounds II. Springer, Berlin, pp 143-203

2. You Y, Park SY (2009) Phosphorescent iridium(III) complexes: toward high phosphorescence quantum efficiency through ligand control. Dalton Trans 8:1267-1282. https://doi.org/10.1039/ B812281D

3. Baranoff E, Yum J-H, Graetzel M, Nazeeruddin MK (2009) Cyclometallated iridium complexes for conversion of light into electricity and electricity into light. J Organomet Chem 694: 2661-2670. https://doi.org/10.1016/j.jorganchem.2009.02.033

4. Chi Y, Chou P-T (2010) Transition-metal phosphors with cyclometalating ligands: fundamentals and applications. Chem Soc Rev 39:638-655. https://doi.org/10.1039/b916237b

5. Ulbricht C, Beyer B, Friebe C et al (2009) Recent developments in the application of phosphorescent iridium(III) complex systems. Adv Mater 21:4418-4441. https://doi.org/10.1002/adma. 200803537

6. Costa RD, Ortí E, Bolink HJ et al (2012) Luminescent ionic transition-metal complexes for light-emitting electrochemical cells. Angew Chem Int Ed Eng 51:8178-8211. https://doi.org/10.1002/ anie. 201201471

7. Hu T, He L, Duan L, Qiu Y (2012) Solid-state light-emitting electrochemical cells based on ionic iridium(III) complexes. J Mater Chem 22:4206-4215. https://doi.org/10.1039/C2JM16185K

8. Hasan K, Donato L, Shen Y et al (2014) Cationic iridium(III) complexes bearing ancillary 2,5-dipyridyl(pyrazine) (2,5-dpp) and 2,2': $5^{\prime}, 2^{\prime \prime}$-terpyridine (2,5-tpy) ligands: synthesis, optoelectronic characterization and light-emitting electrochemical cells. Dalton Trans 43: 13672-13682. https://doi.org/10.1039/C4DT02100B

9. Sun L, Galan A, Ladouceur S et al (2011) High stability lightemitting electrochemical cells from cationic iridium complexes with bulky 5,5' substituents. J Mater Chem 21:18083-18088. https://doi.org/10.1039/C1JM12984H

10. Ning Z, Zhang Q, Wu W, Tian H (2009) Novel iridium complex with carboxyl pyridyl ligand for dye-sensitized solar cells: high fluorescence intensity, high electron injection efficiency? J Organomet Chem 694: 2705-2711. https://doi.org/10.1016/j.jorganchem.2009.02.016

11. Curtin PN, Tinker LL, Burgess CM et al (2009) Structure-activity correlations among iridium(III) photosensitizers in a robust waterreducing system. Inorg Chem 48:10498-10506. https://doi.org/10. 1021/ic9007763

12. McDaniel ND, Coughlin FJ, Tinker LL, Bernhard S (2008) Cyclometalated iridium(III) Aquo complexes: efficient and tunable catalysts for the homogeneous oxidation of water. J Am Chem Soc 130:210-217. https://doi.org/10.1021/ja074478f
13. Lo KK-W, Li SP-Y, Zhang KY (2011) Development of luminescent iridium(III) polypyridine complexes as chemical and biological probes. New J Chem 35:265-287. https://doi.org/10.1039/C0NJ00478B

14. You Y, Nam W (2012) Photofunctional triplet excited states of cyclometalated Ir(III) complexes: beyond electroluminescence. Chem Soc Rev 41:7061-7084. https://doi.org/10.1039/c2cs35171d

15. Xu F, Kim J-H, Kim HU et al (2013) Phosphorescent organic lightemitting diodes fabricated using iridium complexes with carbazolebased benzothiazole ligands. Synth Met 178:10-17. https://doi.org/ 10.1016/j.synthmet.2013.06.023

16. Tung Y-L, Wu P-C, Liu C-S et al (2004) Highly efficient red phosphorescent osmium(II) complexes for OLED applications. Organometallics 23:3745-3748. https://doi.org/10.1021/om0498246

17. Xiang H-F, Chan S-C, KK-Y W et al (2005) High-efficiency red electrophosphorescence based on neutral bis(pyrrole)-diimine platinum(II) complex. Chem Commun 0:1408-1410. https://doi. org/10.1039/B415711G

18. Lamansky S, Djurovich P, Murphy D et al (2001) Highly phosphorescent Bis-Cyclometalated iridium complexes: synthesis, Photophysical characterization, and use in organic light emitting diodes. J Am Chem Soc 123:4304-4312. https://doi.org/10.1021/ ja003693s

19. Xiao L, Chen Z, Qu B et al (2011) Recent progresses on materials for electrophosphorescent organic light-emitting devices. Adv Mater 23:926-952. https://doi.org/10.1002/adma.201003128

20. Chen Z, Bian Z, Huang C (2010) Functional IrIII complexes and their applications. Adv Mater 22:1534-1539. https://doi.org/10. 1002/adma.200903233

21. Benjamin H, Fox MA, Batsanov AS et al (2017) Pyridylpyrazole $\mathrm{N}^{\wedge} \mathrm{N}$ ligands combined with sulfonyl-functionalised cyclometalating ligands for blue-emitting iridium(III) complexes and solution-processable PhOLEDs. Dalton Trans 46:1099611007. https://doi.org/10.1039/C7DT02289A

22. Kim HU, Sohn S, Choi W et al (2018) Substituents engineered deep-red to near-infrared phosphorescence from tris-heteroleptic iridium(III) complexes for solution processable red-NIR organic light-emitting diodes. J Mater Chem C 6:10640-10658. https:// doi.org/10.1039/C8TC04321C

23. Escudero D (2016) Quantitative prediction of photoluminescence quantum yields of phosphors from first principles. Chem Sci 7: 1262-1267. https://doi.org/10.1039/C5SC03153B

24. Urinda S, Das G, Pramanik A, Sarkar P (2018) Essential role of ancillary ligand in color tuning and quantum efficiency of $\operatorname{Ir}(\mathrm{III})$ complexes with $\mathrm{N}$-heterocyclic or Mesoionic Carbene ligand: a comparative quantum chemical study. J Phys Chem A 122:75327539. https://doi.org/10.1021/acs.jpca.8b05376

25. Urinda S, Das G, Pramanik A, Sarkar P (2017) Quantum chemical investigation on the $\operatorname{Ir}(\mathrm{III})$ complexes with an isomeric triazinebased imidazolium carbene ligand for efficient blue OLEDs. Phys Chem Chem Phys 19:29629-29640. https://doi.org/10.1039/ C7CP03299D

26. Escudero D, Jacquemin D (2015) Computational insights into the photodeactivation dynamics of phosphors for OLEDs: a perspective. Dalton Trans 44:8346-8355. https://doi.org/10.1039/ C4DT03804E

27. Urinda S, Das G, Pramanik A, Sarkar P (2016) Theoretical studies on the photophysical properties of some iridium (III) complexes used for OLED. J Phys Chem Solids 96-97:100-106. https://doi. org/10.1016/j.jpcs.2016.05.006

28. Avilov I, Minoofar P, Cornil J, De Cola L (2007) Influence of substituents on the energy and nature of the lowest excited states of heteroleptic phosphorescent Ir(III) complexes: a joint theoretical and experimental study. J Am Chem Soc 129:8247-8258. https:// doi.org/10.1021/ja0711011

29. Urinda S, Das G, Pramanik A, Sarkar P (2016) Tuning the phosphorescence and quantum efficiency of heteroleptic Ir(III) 
complexes based on pyridine-tetrazole as an ancillary ligand: an overview from quantum chemical investigations. Comput Theor Chem 1092:32-40. https://doi.org/10.1016/j.comptc.2016.07.025

30. De Angelis F, Fantacci S, Evans N et al (2007) Controlling phosphorescence color and quantum yields in cationic iridium complexes: a combined experimental and theoretical study. Inorg Chem 46:5989-6001. https://doi.org/10.1021/ic700435c

31. Guo J, Pan X, Wang X et al (2018) Theoretical study on the vibrationally resolved spectra and quantum yield of blue phosphorescent iridium(III) complexes with 2-(4-fluoro-3-(trifluoromethyl)phenyl)pyridine as the cyclometalated ligand. Org Electron 61:125133. https://doi.org/10.1016/j.orgel.2018.06.055

32. Liu Y, Hao Z, Meng F et al (2018) Efficient near-infrared emission of $\pi$-extended cyclometalated iridium complexes based on pyrene in solution-processed polymer light-emitting diode. Chem Phys Lett 699:99-106. https://doi.org/10.1016/j.cplett.2018.03.046

33. Liao J-L, Devereux LR, Fox MA et al (2018) Role of the diphosphine chelate in emissive, charge-neutral iridium(III) complexes. Chem Eur J 24:624-635. https://doi.org/10.1002/chem.201703482

34. Tong B, Wang H, Chen M et al (2018) High efficiency green OLEDs based on homoleptic iridium complexes with steric phenylpyridazine ligands. Dalton Trans 47:12243-12252. https:// doi.org/10.1039/C8DT02781A

35. Choi HJ, Hyun MH, Park HJ, Yoon UC (2017) Synthesis of efficient blue phosphorescent heteroleptic Ir(III) complexes containing 4-alkoxy- or 4-alkylaminopicolinates as ancillary ligands. J Lumin 188:323-330. https://doi.org/10.1016/j.jlumin.2017.04.043

36. Benjamin H, Liang J, Liu Y et al (2017) Color tuning of efficient electroluminescence in the blue and green regions using Heteroleptic iridium complexes with 2-Phenoxyoxazole ancillary ligands. Organometallics 36:1810-1821. https://doi.org/10.1021/ acs.organomet.7b00161

37. Sree VG, Cho W, Shin S et al (2017) Highly efficient solutionprocessed deep-red emitting heteroleptic thiophenephenylquinoline based Ir(III) complexes for phosphorescent organic light-emitting diodes. Dyes Pigments 139:779-787. https://doi. org/10.1016/j.dyepig.2017.01.004

38. Wang X, Feng S, Wang X et al (2017) Theoretical insights into the phosphorescent process of a series of 2-(2-trifluoromethyl) pyrimidine-pyridine based heteroleptic iridium(III) compounds: the influence of the ancillary ligand. Comput Theor Chem 1105: 69-76. https://doi.org/10.1016/j.comptc.2017.02.026

39. Li J, Wang L, Wang X et al (2017) Theoretical perspective of FIrpic derivatives: relationship between structures and photophysical properties. Spectrochim Acta A Mol Biomol Spectrosc 171:425431. https://doi.org/10.1016/j.saa.2016.08.021

40. Liu B, Dang F, Feng Z et al (2017) Novel iridium(III) complexes bearing dimesitylboron groups with nearly $100 \%$ phosphorescent quantum yields for highly efficient organic light-emitting diodes. $\mathrm{J}$ Mater Chem C 5:7871-7883. https://doi.org/10.1039/C7TC02369C

41. Duan Y-C, Wu Y, Ren X-Y et al (2017) From blue to full color theoretical design and characterization of a series of Ir(III) complexes containing azoline ligand with potential application in OLEDs. Dalton Trans 46:11491-11502. https://doi.org/10.1039/ C7DT02684F

42. Cho Y-J, Kim S-Y, Kim J-H et al (2017) Probing photophysical properties of isomeric N-heterocyclic carbene $\mathrm{Ir}(\mathrm{III})$ complexes and their applications to deep-blue phosphorescent organic lightemitting diodes. J Mater Chem C 5:1651-1659. https://doi.org/10. 1039/C6TC04757B

43. Kuo H-H, Chen Y-T, Devereux LR et al (2017) Bis-tridentate Ir(III) metal phosphors for efficient deep-blue organic light-emitting diodes. Adv Mater 29:1702464. https://doi.org/10.1002/adma.201702464

44. Elie M, Renaud J-L, Gaillard S (2018) N-heterocyclic carbene transition metal complexes in light emitting devices. Polyhedron 140: 158-168. https://doi.org/10.1016/j.poly.2017.11.045
45. Zhang Q, Wang X, Zhang Y et al (2016) Insight into the phosphorescent process of Cyclometalated Ir(III) complexes: combination of the substituents on primary and ancillary ligands controls the emission rule and quantum yield. J Phys Chem C 120:2752327532. https://doi.org/10.1021/acs.jpcc.6b07562

46. Li T-Y, Wu J, Wu Z-G et al (2018) Rational design of phosphorescent iridium(III) complexes for emission color tunability and their applications in OLEDs. Coord Chem Rev 374:55-92. https://doi. org/10.1016/j.ccr.2018.06.014

47. Liu X, Yao B, Wang H et al (2018) Efficient solution-processed yellow/orange phosphorescent OLEDs based on heteroleptic Ir(III) complexes with 2-(9,9-diethylfluorene-2-yl)pyridine main ligand and various ancillary ligands. Org Electron 54:197-203. https://doi.org/10.1016/j.orgel.2017.12.050

48. Zhong Z, Lian H, Wu J et al (2018) Efficient blue phosphorescent organic light-emitting diodes enabled by ag-nanoparticlesembedded hole transporting layer. Org Electron 56:31-36. https:// doi.org/10.1016/j.orgel.2018.01.021

49. Cai Y, Shi C, Zhang H et al (2018) Sulfur-bridged tetraphenylethylene AIEgens for deep-blue organic light-emitting diodes. J Mater Chem C 6:6534-6542. https://doi.org/10.1039/ C8TC01509K

50. Yan Z, Wang Y, Ding J et al (2017) Methoxyl modification in furo[3,2-c]pyridine-based iridium complexes towards highly efficient green- and orange-emitting electrophosphorescent devices. J Mater Chem C 5:12221-12227. https://doi.org/10.1039/ C7TC04269H

51. Kumar S, Surati KR, Lawrence R et al (2017) Design and synthesis of heteroleptic iridium(III) phosphors for efficient organic lightemitting devices. Inorg Chem 56:15304-15313. https://doi.org/10. 1021/acs.inorgchem. 7b02872

52. Esteruelas MA, Gómez-Bautista D, López AM et al (2017) ๆ1Arene complexes as intermediates in the preparation of molecular phosphorescent iridium(III) complexes. Chem Eur J 23:1572915737. https://doi.org/10.1002/chem.201703252

53. Shi C, Li Q, Zou L et al (2018) A single-anion-based red-emitting cationic diiridium(III) complex bearing a pyrimidine-based bridging ligand for oxygen sensing. Eur J Inorg Chem 2018:1131-1136. https://doi.org/10.1002/ejic.201800004

54. Hu W-K, Li S-H, Ma X-F et al (2018) Blue-to-green electrophosphorescence from iridium(III) complexes with cyclometalated pyrimidine ligands. Dyes Pigments 150:284-292. https://doi.org/10.1016/j.dyepig.2017.12.020

55. Li J, Tian Z, Xu Z et al (2018) Highly potent half-sandwich iridium and ruthenium complexes as lysosome-targeted imaging and anticancer agents. Dalton Trans 47:15772-15782. https://doi.org/10. 1039/C8DT02963F

56. Miao Y, Tao P, Gao L et al (2018) Highly efficient chlorine functionalized blue iridium(III) phosphors for blue and white phosphorescent organic light-emitting diodes with the external quantum efficiency exceeding 20\%. J Mater Chem C 6:6656-6665. https:// doi.org/10.1039/C8TC01098F

57. Zanoni KPS, Ito A, Grüner M et al (2018) Photophysical dynamics of the efficient emission and photosensitization of [Ir(pqi)2(NN)]+ complexes. Dalton Trans 47:1179-1188. https://doi.org/10.1039/ C7DT03930A

58. Molaee H, Nabavizadeh SM, Jamshidi M et al (2017) Phosphorescent heterobimetallic complexes involving platinum(IV) and rhenium(VII) centers connected by an unsupported $\mu$-oxido bridge. Dalton Trans 46:16077-16088. https:// doi.org/10.1039/C7DT03126B

59. Congrave DG, Batsanov AS, Du M et al (2018) Intramolecular $\pi-\pi$ interactions with a chiral auxiliary ligand control Diastereoselectivity in a Cyclometalated Ir(III) complex. Inorg Chem 57:12836-12849. https://doi.org/10.1021/acs.inorgchem. 8 b02034 
60. Zou J, Wu H, Lam C-S et al (2011) Simultaneous optimization of charge-carrier balance and luminous efficacy in highly efficient white polymer light-emitting devices. Adv Mater 23:2976-2980. https://doi.org/10.1002/adma.201101130

61. Baranoff E, Fantacci S, De Angelis F et al (2011) Cyclometalated iridium(III) complexes based on phenyl-imidazole ligand. Inorg Chem 50:451-462. https://doi.org/10.1021/ic901834v

62. Park H-R, Ha Y (2012) Introduction of the benzoquinoline ancillary ligand to the iridium complexes for organic light-emitting diodes. J Nanosci Nanotechnol 12:1365-1370

63. Karatsu T, Nakamura T, Yagai S et al (2003) Photochemical mer $\rightarrow$ fac one-way isomerization of phosphorescent material. Studies by time-resolved spectroscopy for Tris $\left[2-\left(4^{\prime}, 6^{\prime}-\right.\right.$ difluorophenyl)pyridine]iridium(III) in solution. Chem Lett 32: 886-887. https://doi.org/10.1246/cl.2003.886

64. Laskar IR, Hsu S-F, Chen T-M (2005) Syntheses, photoluminescence and electroluminescence of some new blueemitting phosphorescent iridium(III)-based materials. Polyhedron 24:189-200. https://doi.org/10.1016/j.poly.2004.10.016

65. McDonald AR, Lutz M, von Chrzanowski LS et al (2008) Probing the mer- to fac-isomerization of tris-cyclometallated homo- and heteroleptic (C,N)3 iridium(III) complexes. Inorg Chem 47:66816691. https://doi.org/10.1021/ic800169n

66. Tsuchiya K, Ito E, Yagai S et al (2009) Chirality in the photochemical mer $\rightarrow$ fac geometrical isomerization of Tris(1phenylpyrazolato,N,C2')iridium(III). Eur J Inorg Chem 2009: 2104-2109. https://doi.org/10.1002/ejic.200801254

67. Becke AD (1993) Density-functional thermochemistry. III. The role of exact exchange. J Chem Phys 98:5648-5652. https://doi.org/10. $1063 / 1.464913$

68. Stephens PJ, Devlin FJ, Chabalowski CF, Frisch MJ (1994) Ab initio calculation of vibrational absorption and circular dichroism spectra using density functional force fields. J Phys Chem 98: 11623-11627. https://doi.org/10.1021/j100096a001

69. Kim K, Jordan KD (1994) Comparison of density functional and MP2 calculations on the water monomer and dimer. J Phys Chem 98:10089-10094. https://doi.org/10.1021/j100091a024

70. Clark T, Chandrasekhar J, Spitznagel GW, Schleyer PVR (1983) Efficient diffuse function-augmented basis sets for anion calculations. III. The $3-21+\mathrm{G}$ basis set for first-row elements, Li-F. J Comput Chem 4:294-301. https://doi.org/10.1002/jcc.540040303

71. Zhao Y, Truhlar DG (2008) The M06 suite of density functionals for main group thermochemistry, thermochemical kinetics, noncovalent interactions, excited states, and transition elements: two new functionals and systematic testing of four M06-class functionals and 12 other functionals. Theor Chem Accounts 120:215241. https://doi.org/10.1007/s00214-007-0310-x

72. Chai J-D, Head-Gordon M (2008) Systematic optimization of longrange corrected hybrid density functionals. J Chem Phys 128: 084106. https://doi.org/10.1063/1.2834918

73. Francl MM, Pietro WJ, Hehre WJ et al (1982) Self-consistent molecular orbital methods. XXIII. A polarization-type basis set for second-row elements. J Chem Phys 77:3654-3665. https://doi. org/10.1063/1.444267

74. Hay PJ, Wadt WR (1985) Ab initio effective core potentials for molecular calculations. Potentials for the transition metal atoms Sc to Hg. J Chem Phys 82:270-283. https://doi.org/10.1063/1. 448799

75. Cancès E, Mennucci B, Tomasi J (1997) A new integral equation formalism for the polarizable continuum model: theoretical background and applications to isotropic and anisotropic dielectrics. J Chem Phys 107:3032-3041. https://doi.org/10.1063/1.474659

76. Mennucci B, Tomasi J (1997) Continuum solvation models: a new approach to the problem of solute's charge distribution and cavity boundaries. J Chem Phys 106:5151-5158. https://doi.org/10.1063/ 1.473558

77. Cossi M, Barone V, Mennucci B, Tomasi J (1998) Ab initio study of ionic solutions by a polarizable continuum dielectric model. Chem Phys Lett 286:253-260. https://doi.org/10.1016/S0009-2614(98) 00106-7

78. Witkowska E, Wiosna-Salyga G, Glowacki I et al (2018) Effect of fluorine substitution of the $\beta$-ketoiminate ancillary ligand on photophysical properties and electroluminescence ability of new iridium(III) complexes. J Mater Chem C 6:8688-8708. https://doi. org $/ 10.1039 /$ C8TC02890G

79. Orwat B, Witkowska E, Kownacki I et al (2017) Microwaveassisted one-pot synthesis of new ionic iridium complexes of $\left[\operatorname{Ir}(\mathrm{bzq}) 2\left(\mathrm{~N}^{\wedge} \mathrm{N}\right)\right]+\mathrm{a}-$ type and their selected electroluminescent properties. Dalton Trans 46:9210-9226. https://doi.org/10.1039/ C7DT01372H

80. Frisch MJ, Trucks GW, Schlegel HB et al (2016) Gaussian16 revision B.01. Gaussian Inc, Wallingford

81. Lamansky S, Djurovich P, Murphy D et al (2001) Synthesis and characterization of phosphorescent cyclometalated iridium complexes. Inorg Chem 40:1704-1711. https://doi.org/10.1021/ ic0008969

82. Konno H, Ito T, Sugita Y (2013) Method for producing complex of trisortho-metalated iridium, light-emitting material using said complex, and light-emitting element. Patent: US9200023

83. Daniels RE, Culham S, Hunter M et al (2016) When two are better than one: bright phosphorescence from non-stereogenic dinuclear iridium(III) complexes. Dalton Trans 45:6949-6962. https://doi. org/10.1039/C6DT00881J

84. González I, Dreyse P, Cortés-Arriagada D et al (2015) A comparative study of $\operatorname{Ir}(\mathrm{III})$ complexes with pyrazino[2,3-f][1, 10]phenanthroline and pyrazino[2,3-f][4,7]phenanthroline ligands in light-emitting electrochemical cells (LECs). Dalton Trans 44: 14771-14781. https://doi.org/10.1039/C5DT01385B

85. Henwood AF, Pal AK, Cordes DB et al (2017) Blue-emitting cationic iridium(III) complexes featuring pyridylpyrimidine ligands and their use in sky-blue electroluminescent devices. J Mater Chem C 5:9638-9650. https://doi.org/10.1039/C7TC03110F

86. Frey J, Curchod BFE, Scopelliti R et al (2014) Structure-property relationships based on Hammett constants in cyclometalated iridium(III) complexes: their application to the design of a fluorine-free FIrPic-like emitter. Dalton Trans 43:5667-5679. https://doi.org/10.1039/C3DT52739E

87. Liu X, Zhang S, Jin Y-M et al (2015) Syntheses, crystal structure and photophysical property of iridium complexes with $1,3,4$ oxadiazole and 1,3,4-thiadiazole derivatives as ancillary ligands. J Organomet Chem 785:11-18. https://doi.org/10.1016/j. jorganchem.2015.02.025

88. Jing Y-M, Zheng Y-X (2017) Photoluminescence and electroluminescence of deep red iridium(III) complexes with 2,3diphenylquinoxaline derivatives and 1,3,4-oxadiazole derivatives ligands. RSC Adv 7:37021-37031. https://doi.org/10.1039/ C7RA05530G

89. Chen L, Doeven EH, Wilson DJD et al (2017) Co-reactant electrogenerated chemiluminescence of iridium(III) complexes containing an acetylacetonate ligand. ChemElectroChem 4:17971808. https://doi.org/10.1002/celc.201700222

90. González I, Cortés-Arriagada D, Dreyse P et al (2015) A family of IrIII complexes with high nonlinear optical response and their potential use in light-emitting devices. Eur J Inorg Chem 2015:49464955. https://doi.org/10.1002/ejic.201500505

Publisher's note Springer Nature remains neutral with regard to jurisdictional claims in published maps and institutional affiliations. 